\title{
Macroinvertebrates of Eichhornia crassipes (Pontederiaceae) roots in the alluvial floodplain of large tropical rivers (Argentina)
}

\author{
Alicia S. G. Poi ${ }^{1}$, Juan J. Neiff ${ }^{1}$, Sylvina L. Casco ${ }^{1,2}$ \& Luciana I. Gallardo ${ }^{1,2}$ \\ 1. Centro de Ecología Aplicada del Litoral- CECOAL (CCT Nordeste - CONICET- UNNE), Ruta 5 km 2.5, (3400) \\ Corrientes, Argentina; guadalupepoi@gmail.com; jj@neiff.com.ar \\ 2. Facultad de Ciencias Exactas y Naturales y Agrimensura-FACENA, Universidad Nacional del Nordeste-UNNE, \\ (3400) Corrientes, Argentina; sylvina.casco@gmail.com; lucianagallardo@hotmail.com
}

Received 30-IX-2019. Corrected 07-VIII-2020. Accepted 31-VIII-2020.

\begin{abstract}
Introduction: Eichhornia crassipes is a dominant aquatic plant of neotropical-river floodplains and is invasive in warm waters of different continents. Plants provide food and habitat for fish, especially Prochilodus lineatus and Gymnotus omarorum, which are relevant to subsistence fishing by local indigenous communities. Objective: In this study we describe the main traits of E. crassipes floating meadows, and analyze the abundance and composition of macroinvertebrate assemblages associated with their roots in two floodplain wetlands of the Paraná River (within the Ramsar site Wetlands Chaco) and of the Pilcomayo River (within the Pilcomayo River National Park). Methods: During spring and summer, the macroinvertebrates were collected in monospecific stands of E. crassipes with a net of $962 \mathrm{~cm}^{2}$ area and $500 \mu \mathrm{m}$ mesh size. Leaf density, the biomass of leaves and roots, the length of leaves and roots, and the water quality were measured simultaneously. Results: Temperature, oxygen concentration, and nutrient content were significantly higher and electrical conductivity was lower in the Pilcomayo than in the Paraná floodplain. E. crassipes growing in the Pilcomayo floodplain had longer leaves and less root biomass than those found in the Paraná floodplain. The number of macroinvertebrates per $1000 \mathrm{~g}$ root dry weight and per $\mathrm{m}^{2}$ was significantly different between both floodplains, but the taxon richness was similar. Non Metric Multidimensional Scaling analysis differentiated the abundance of 14 selected taxa between both floodplains, and showed a high correlation between the environmental variables and macroinvertebrate abundance. The most abundant taxonomic groups in the Paraná River floodplain were oligochaetes (Naididae), ostracods mainly Cytheridella ilosvayi and larvae of non-biting midges (Chironomidae). Two families, Hydrobiidae (Heleobia parchappii) and Chironomidae accounted for $49.3 \%$ of the total abundance in the Pilcomayo floodplain. The prawns Macrobrachium jelskii and M. amazonicum, frequent in the Pilcomayo floodplain, were not found in the Paraná floodplain. Conclusions: The different environmental conditions in both floodplains affect the abundance, composition, and the dominance of macroinvertebrate assemblages; however, the total taxa richness was similar. The area occupied by E. crassipes in the floodplains of these rivers provides the habitat that contributes most to overall biotic diversity, which must be considered in management strategies.
\end{abstract}

Key words: water hyacinth; Paraná and Pilcomayo Rivers; floodplains; macroinvertebrate abundance; taxon richness.

Poi, A.S.G., Neiff, J.J., Casco, S.L., \& Gallardo, L.I. (2020). Macroinvertebrates of Eichhornia crassipes (Pontederiaceae) roots in the alluvial floodplain of large tropical rivers (Argentina). Revista de Biología Tropical, 68(Suppl. 2), S104-S115.

Originally from South America, the freefloating aquatic plant Eichhornia crassipes (known as water hyacinth, camalote, aguapé) has invaded warm waters in over 50 countries on five continents (Villamagna \& Murphy
2010). Floating meadow is a typical feature of the floodplain of large South American rivers such as Paraguay, Orinoco, and Pilcomayo. E. crassipes is the most frequent species in the floodplains of the Paraná River occupying 
the lakes that receive the frequent overflow of the river (Neiff, Casco, Mari, Di Rienzo, $\&$ Poi 2014), where may cover $30-100 \%$ of the available surface of the lakes. In the low water phase, plants grow limited by nitrogen (Carignan \& Neiff 1992) and during prolonged floods increase leaf length, leaf biomass and nutrient content in green leaves and decrease root biomass (Neiff, Casco, \& Poi 2008).

The submerged roots are colonized by more than 79 taxa of macroinvertebrates in the Paraná River floodplain (Poi de Neiff $\&$ Neiff 2006). Above the water line, leaves have less species richness, mostly herbivorous (Franceschini, Poi de Neiff, \& Galassi 2010). The abundance of macroinvertebrates on E. crassipes roots varied between 5395 and 24116 ind. $\mathrm{m}^{2}$ depending on the four variables: hydrological period, site, conductivity, and dissolved oxygen (Poi de Neiff \& Carignan 1997). These values can be more than six times greater when samples include macroinvertebrates captured with mesh between 500 and $100 \mu \mathrm{m}$ (Blanco Belmonte, Neiff, \& Poi de Neiff 1998).

The diet of the dominant fish of the Paraná River floodplain had a high frequency of organisms associated with the floating macrophytes (Neiff, Poi de Neiff, \& Canón Verón 2008). Plants provide food and habitat for fish, especially Prochilodus lineatus and Gymnotus omarorum, which are relevant for subsistence fishing by local indigenous communities in the Pilcomayo floodplain. According to Ferriz and Iwaszkiw (2014), G. omarorum feeds preferentially on larvae of odonates, shrimp and other macroinvertebrates living in the roots of $E$. crassipes.

Habitat complexity defined by the type of plant community that occurs in a wetland is one of the fundamental drivers that determine the distribution of macroinvertebrate assemblages because the different architectures and growth forms of aquatic plants affect their abundance, species richness, biomass and trophic structure (Batzer \& Wissinger 1996, Thomaz, Dibble, Evangelista, Higuti \& Bini 2008).

In order to investigate how much of the variation in macroinvertebrate assemblages is explained by the environmental factors, we aimed to describe the main traits of $E$. crassipes floating meadows, and analyze the abundance and composition of macroinvertebrate assemblages associated with their roots in two protected floodplain wetlands of the Paraná River (within the Ramsar site Wetlands Chaco) and of the Pilcomayo River (within the Pilcomayo River National Park). We hypothesized that $1)$ the traits of E. crassipes floating meadows and 2) the abundance and composition of macroinvertebrates associated with their roots vary in sites with different water and climate conditions. We predicted that E. crassipes floating meadows should respond to environmental changes (Carignan, Neiff \& Planas 1994) and that longest root should appear when $E$. crassipes growing limited by nitrogen (Carignan \& Neiff 1992). Under these circumstances, the macroinvertebrates associated with the root system should be dominated by tolerant species to oxygen depletion (Poi de Neiff \& Carignan 1997).

\section{MATERIALS AND METHODS}

Study sites: We selected two floodplain lakes, $263 \mathrm{~km}$ distant, in the northeastern region of Argentina, where E. crassipes was found in monospecific stands with similar coverage. Laguna Blanca Lake (25 09'48' $\mathrm{S}$ and $58^{\circ} 08^{\prime} 51^{\prime \prime} \mathrm{W}$ ) is the unique floodplain lake located on the paleochannel-bed of the lower Pilcomayo River (Formosa) and El Puente Lake (27 $26^{\prime} 23^{\prime \prime} \mathrm{S}$ and $\left.58^{\circ} 51^{\prime} 19^{\prime \prime} \mathrm{W}\right)$ is located on the alluvial plain of the Paraná River (Chaco) downstream of the Paraná-Paraguay River confluence. Laguna Blanca (Fig. 1) is a shallow lake (1.60-1.90 m) with an approximate surface of 800 ha. The floating meadow with the absolute dominance of E. crassipes covers $10-20 \%$ of the surface, distributed in a strip of three to 15 meters wide. This protected lake (within the Pilcomayo National Park), has warm water with high dissolved oxygen and nutrients availability. The water is turbid due to the abundance of silt and clay and has low 
to moderate salinity. The ionic typology is: $\mathrm{HCO}_{3}^{-}>\mathrm{Na}^{+}>\mathrm{K}^{+}>\mathrm{Cl}^{-}>\mathrm{SO}_{4}^{-}>\mathrm{Mg}^{+}>\mathrm{Ca}^{+}$.

El Puente Lake belongs to a complex of several similar oxbow lakes (Fig. 1) located parallel to, and approximately $2 \mathrm{~km}$ from the Paraná River, and was selected based on the expertise accredited by previous research in the study area. It is small $(200 \times 3000 \mathrm{~m})$, shallow ( $0.90-2.5 \mathrm{~m}$ deep) and separated from the river by alluvial levees (10 - $20 \mathrm{~m}$ wide, $1-2 \mathrm{~m}$ high) occupied by gallery forests. Water hyacinth covered $40-60 \%$ of its surface. The lake is fed periodically by the overflows of the Paraná River, but the frequency, duration, and timing of the connections vary with river stage.
During the study period, the Paraná was at low water and the lake disconnected from the river.

The waters have moderate salinity and low nutrient content (Carignan \& Neiff 1992) and belong to the ionic typology: $\mathrm{HCO}_{3}^{->} \mathrm{Na}^{+}>$ $\mathrm{Cl}^{-}>\mathrm{Mg}^{+}>\mathrm{SO}_{4}>\mathrm{Ca}^{+}>\mathrm{K}^{+}$.

Sampling methods: Macroinvertebrates were collected using a $35 \mathrm{~cm}$ diameter net, with $500 \mu \mathrm{m}$ mesh size and $962 \mathrm{~cm}^{2}$ area (Poi de Neiff \& Carignan 1997, USEPA 2002). The net with a $1.5 \mathrm{~m}$ long handle, operated from a boat, was introduced vertically under the roots (70 $\mathrm{cm}$ depth approximately) by lifting it into a horizontal position. During October and

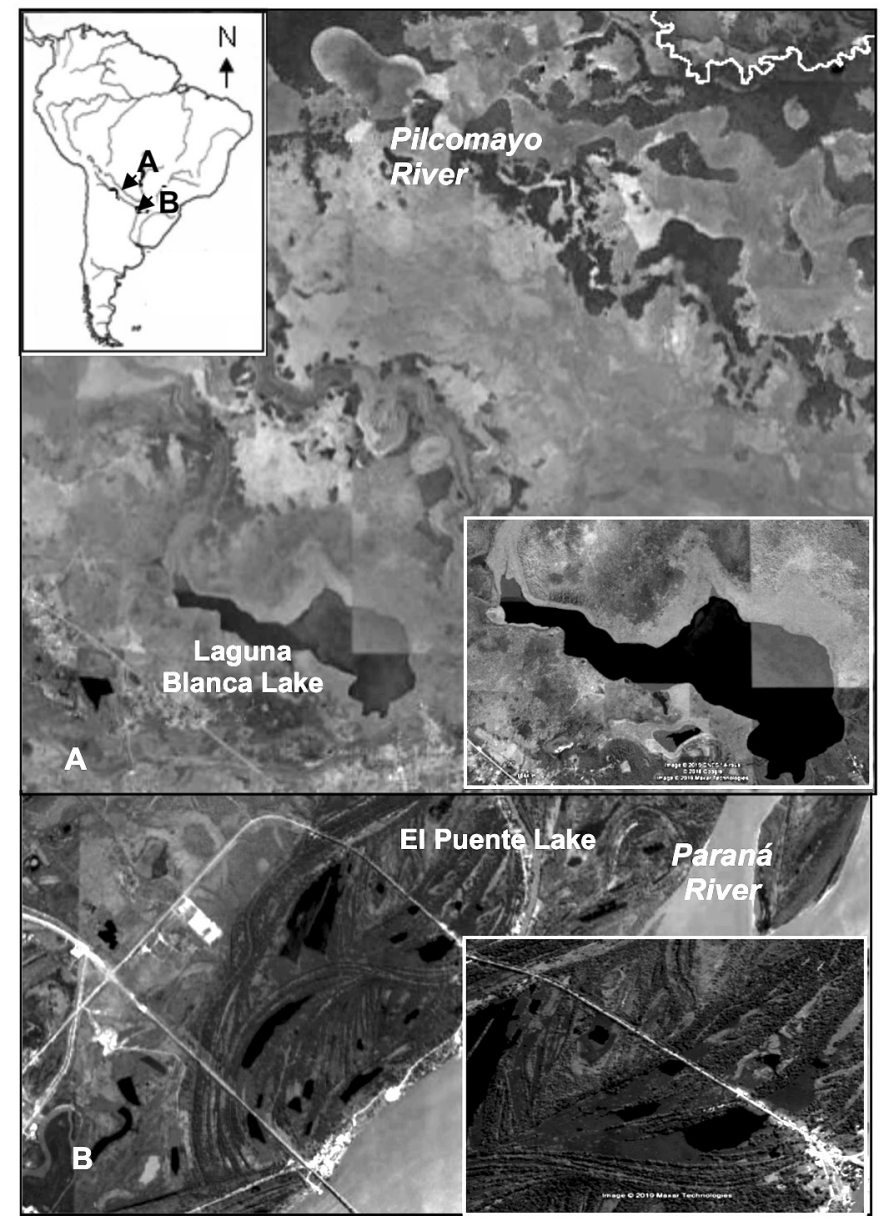

Fig. 1. Study sites A. Laguna Blanca Lake (within the Pilcomayo National Park and B. El Puente Lake in the Paraná River floodplain (within the Ramsar site Wetlands Chaco). 
December 2012, 13 samples were obtained in El Puente Lake and 11 in Laguna Blanca Lake. Each sample constituted a discrete representation of plant and macroinvertebrate material collected from independent stands separated by $5 \mathrm{~m}$ from each other. At each point, two pseudo-replicates were extracted.

In the laboratory, the aquatic plants were thoroughly washed to detach the macroinvertebrates, and the obtained suspensions were filtered through sieves of $1 \mathrm{~mm}$ and $500 \mu \mathrm{m}$ and preserved in $70 \%$ ethanol. Macroinvertebrates were counted and identified to the lowest practical taxonomic level (usually family) using keys from Michat, Archangelsky \& Bachmann (2008), Domínguez \& Fernández (2009), Ramírez (2010) and Libonatti, Michat $\&$ Torres (2011). The macroinvertebrate abundance was expressed as individuals per $1000 \mathrm{~g}$ roots dry weight and number of individuals per square meter.

At both floodplains, plants of water hyacinth with elongate leaves (large biotype), which occurs in dense mats, were dominant. The short inflated petiole with wider than long laminas (small biotype), which occurs in more open conditions, was exceptionally found during the study period. The mean number of leaves was determined on a circular plot of 0.30 $\mathrm{m}^{2}$ in each point where the macroinvertebrates were collected. All plants in the plot were cut and collected in plastic bags. In the laboratory, the leaves were separated and counted. The length of the green leaves was measured from the base of the petiole to the end of the leaf. The root length was measured from the rhizome to the end of the root cluster. The green leaves and roots were washed and dried at $105{ }^{\circ} \mathrm{C}$ for 72 hours to obtain constant dry weight.

Measurements of the limnological characteristics were taken inside the floating meadows and simultaneously with the collection of the macroinvertebrate samples. Water temperature, electrical conductivity, and oxygen concentration were measured with an YSI 54A polarographic probe, conductivity was recorded with an YSI $33 \mathrm{SCT}$ device, and $\mathrm{pH}$ was measured with a WTW 330/SET-1 digital $\mathrm{pH}$ meter.

For nutrient analyses, water samples were filtered within $1-2 \mathrm{~h}$ of collection on prewashed Gelman DM-450 (0.45 mm - pore) membranes for spectrophotometric analyses of $\mathrm{NH}_{4}^{+}$(indophenol blue method), $\mathrm{NO}_{3}^{-}+$ $\mathrm{NO}_{2}^{-}$(called $\mathrm{NO}_{3}^{-}$) by $\mathrm{Cd}$ reduction and orthophosphate called Phosphate (molybdenum blue method) with persulfate oxidation (APHA 1995). The chlorophyll- $a$ concentration was measured by the fluorometric method in 500 $\mathrm{ml}$ water samples taken adjacent to floating meadows at a depth of $20 \mathrm{~cm}$. After 24 hours of acetone maceration, the algal suspensions were filtered onto Whatman GF/C filters of 0.7 a $1.2 \mu \mathrm{m}$.

Data Analyses: The non-parametric Kruskal-Wallis test was used to detect significant differences between both floodplains taking into account the limnological characteristics, the traits of E. crassipes floating meadows and the abundance of macroinvertebrates.

The abundance (ind. $\mathrm{m}^{2}$ ) of 14 macroinvertebrate taxa (those were more frequent and abundant) and the environmental variables that had significant differences between both floodplains (temperature, dissolved oxygen, electrical conductivity, $\mathrm{pH}, \mathrm{PO}_{4}{ }^{3-}, \mathrm{NO}_{3}{ }^{-}$, roots length and roots dry weight) were ordered using a Non-Metric Multidimensional Scaling (NMDS). To evaluate statistical differences in the abundance of the macroinvertebrate taxa between both floodplains, a Analysis of Similarities (ANOSIM), were performed (Clarke 1993), using the Bray-Curtis distance and 9999 random permutations to estimate the significance of the $\mathrm{R}$ statistic associated with ANOSIM. Prior to this analysis, abundance data have been standardized through logarithmic transformation $\left(\log _{10} x+1\right)$. The statistical analyses were performed using InfoStat (Di Rienzo, Casanoves, Balzarini, González, Tablada \& Robledo 2013) and PAST 2.08 (Hammer, Harper \& Ryan 2001) software. 


\section{RESULTS}

Water condition: Temperature $(\mathrm{H}=16.5$, $\mathrm{p}<0.0001)$, dissolved oxygen $(\mathrm{H}=16.5$, $\mathrm{p}<0.0001)$, phosphate content $(\mathrm{H}=16.5$, $\mathrm{p}<0.0001)$ and nitrate concentration $(\mathrm{H}=14.73$, $\mathrm{p}<0.0001)$ were significantly higher in the Pilcomayo than in the Paraná floodplain (Table 1). Although the differences in $\mathrm{pH}$ between both floodplains were significant with the test used $(\mathrm{H}=9.60, \mathrm{p}=0.0019)$, the values found were close to neutrality. Transparency did not show significant differences $(H=1.74, p=0.1862)$ between both floodplains. Electrical conductivity (Table 1) was significantly higher in the Paraná than in the Pilcomayo floodplain $(\mathrm{H}=$ $15, \mathrm{p}=0.0001$ ). The mean chlorophyll $a$ (Table 1) was lower than $1.7 \mu \mathrm{g} . \mathrm{l}^{-1}$.

Plant traits and biomass: Leaf density was significantly higher in the Paraná than in the Pilcomayo floodplain $(\mathrm{H}=4.92, \mathrm{p}=0.0265)$. However, the green leaf biomass $(H=15.25$, $\mathrm{p}=0.0001)$ and height $(\mathrm{H}=18.72, \mathrm{p}<0.0001)$ were higher in the Pilcomayo (Table 1). Finally, the root biomass $(\mathrm{H}=17.16, \mathrm{p}<0.0001)$ and the root length $(\mathrm{H}=19.5, \mathrm{p}<0.0001)$ were higher in the Paraná, where they reached a maximum length of $84 \mathrm{~cm}$ (Table 1).

Abundance and richness of macroinvertebrate assemblages: The number of macroinvertebrates per $1000 \mathrm{~g}$ roots dry weight $(\mathrm{H}=7.9, \mathrm{p}=0.005)$ and per square meter $(\mathrm{H}=$ $8.56, \mathrm{p}=0.0034$ ) differed significantly between the floodplains (Table 1). Note that the number of macroinvertebrates per $1000 \mathrm{~g}$ roots dry weight was higher in the Pilcomayo floodplain than in the Paraná floodplain due to the lower root weight for the same surface unit. A total of 44 families of macroinvertebrates (34 in the Paraná and 33 in the Pilcomayo floodplain) from 11 major groups were recorded (Table 2), with 25 families in common.

The most abundant taxonomic groups on water hyacinth roots (Fig. 2) in the Paraná

TABLE 1

Traits of E. crassipes stands, water condition and overall macroinvertebrate abundance in the floating meadows of the Paraná and Pilcomayo floodplain between October and December 2012

\begin{tabular}{|c|c|c|}
\hline & Paraná & Pilcomayo \\
\hline \multicolumn{3}{|l|}{ Traits of $E$. crassipes } \\
\hline Leaf density per $\mathrm{m}^{2}$ & $290 \pm 39.6$ & $270 \pm 28.5$ \\
\hline Leaf biomass per $\mathrm{m}^{2}$ & $817 \pm 110$ & $1100 \pm 335$ \\
\hline Mean leaf height $(\mathrm{cm})$ & $68 \pm 12$ & $89 \pm 26$ \\
\hline Mean root length $(\mathrm{cm})$ & $74 \pm 10$ & $42 \pm 18$ \\
\hline Mean root biomass g. $\mathrm{m}^{2}$ & $450 \pm 69$ & $379 \pm 41$ \\
\hline \multicolumn{3}{|l|}{ Water condition } \\
\hline Temperature $\left({ }^{\circ} \mathrm{C}\right)$ & $23.5 \pm 0.7$ & $30.4 \pm 2.4$ \\
\hline Transparency $(\mathrm{cm})$ & $47.6 \pm 18.0$ & $27 \pm 11.4$ \\
\hline Conductivity $\left(\mu \mathrm{S} . \mathrm{cm}^{-1}\right)$ & $262 \pm 36.2$ & $169.3 \pm 28$ \\
\hline Dissolved oxygen (mg. $\mathrm{l}^{-1}$ ) & $2.8 \pm 1.1$ & $6.6 \pm 0.96$ \\
\hline $\mathrm{pH}$ & $6.5 \pm 0.3$ & $7.2 \pm 0.8$ \\
\hline $\mathrm{NO}_{3}-\mathrm{N}\left(\mu \mathrm{g} \cdot \mathrm{l}^{-1}\right)$ & Bdl & $76.6 \pm 53.1$ \\
\hline $\mathrm{NH}_{4}-\mathrm{N}\left(\mu \mathrm{g} \cdot \mathrm{l}^{-1}\right)$ & $70 \pm 19.7$ & $78.3 \pm 14.2$ \\
\hline $\mathrm{PO}_{4}-\mathrm{P}\left(\mu \mathrm{g} .1^{-1}\right)$ & $24.2 \pm 24.7$ & $343.3 \pm 105.2$ \\
\hline Chlorophylla $\left(\mu \mathrm{g} . \mathrm{l}^{-1}\right)$ & $1.7 \pm 0.47$ & Bdl \\
\hline \multicolumn{3}{|l|}{ Macroinvertebrate abundance } \\
\hline Number of Individuals per $1000 \mathrm{~g}$ roots dry weight & $17009 \pm 5981$ & $24580 \pm 3752$ \\
\hline Number of Individuals per $\mathrm{m}^{2}$ & $6244 \pm 1654$ & $4198 \pm 1213$ \\
\hline
\end{tabular}

$\mathrm{Bdl}=$ below the detection limit. 
River floodplain were oligochaetes (Naididae, $19.7 \%$ ), ostracods (Limnocytheridae mainly Cytheridella ilosvayi, $16.67 \%)$ and larvae of non biting midges (Chironomidae, $12.59 \%$ ). Two families Hydrobiidae (Heleobia parchappii) and Chironomidae (larvae and pupae) account for $49.3 \%$ of the total abundance in the Pilcomayo floodplain.

The differences between both floodplains were significantly for Naididae $(\mathrm{H}=13.11$, $\mathrm{p}=0.0003)$, Limnocytheridae $(\mathrm{H}=17.16, \mathrm{p}$ $=0.0001)$ and Hydrobiidae $(\mathrm{H}=16.5, \mathrm{p}=0.0001)$.

Amphipods (Hyalella curvispina) were significantly more abundant $(\mathrm{H}=6.50, \mathrm{p}=0.01)$ in the Pilcomayo floodplain and, Glossiphoniidae $(H=17.16, p=0.0001)$ and Dytiscidae $(\mathrm{H}=14.18, \mathrm{p}=0.0002)$ in the Paraná floodplain. Palaemonidae (Macrobrachium jelskii and $M$. amazonicum) had a mean abundance of $77 \pm 46$ ind. $\mathrm{m}^{2}$ in the Pilcomayo floodplain, and they were not found in the Paraná floodplain (Fig. 2).

Euryalona occidentalis (Chydoridae) and Grimaldina brazzai (Macrothricidae) were the dominant cladocerans associated with E. crassipes in the Paraná River floodplain. Simocephalus vetulus (Daphnidae) was a more frequent cladoceran in the Pilcomayo floodplain, but the counts were made at the Order level (Table 2). The two species of weevils (Neochetina bruchi and N. eichhorniae) feed on the leaves but during the day were found near the stems. Its abundance reached 176 ind. $\mathrm{m}^{2}$ in the Pilcomayo floodplain. The other taxa had low relative abundance (Table 2).

The NMDS results reflected the differences in the abundances of macroinvertebrate taxa (mostly at family-level) between both floodplains (ANOSIM: $\mathrm{R}=0.93, \mathrm{p}=0.0001$ ) and the ordination had low final stress $(9.2 \%)$. The NMDS ordination separated the abundances of macroinvertebrate taxa found in the Pilcomayo and Paraná floodplains, which are grouped on the right and left of the first axis, respectively (Fig. 3). When environmental variables were analyzed, the NMDS ordination showed that some of these variables were highly correlated with the gradients in macroinvertebrate taxa

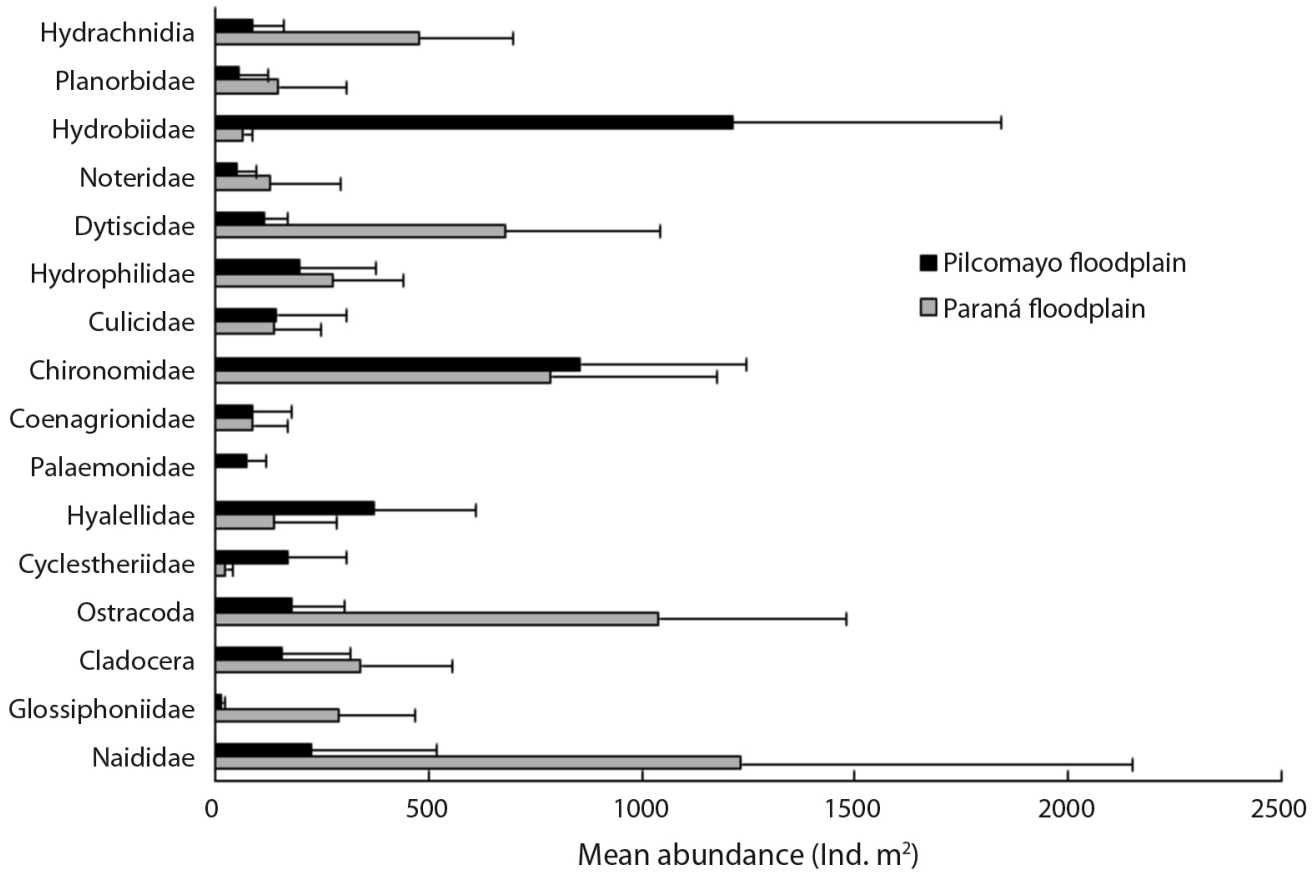

Fig. 2. Mean macroinvertebrate abundance of the main taxa registered at both floodplains. 
TABLE 2

Comparison of the mean relative abundance of macroinvertebrates associated with E. crassipes between Laguna Blanca (Pilcomayo River floodplain) and El Puente oxbow (Paraná River floodplain). References: + presence, - absence.

\section{OLIGOCHAETA}

Naididae

Pilcomayo Paraná

Lumbricumorpha

OSTRACODA

Limnocytheridae, Cytheridella ilosvayi (Daday)

HIRUDINEA

Glossiphoniidae

$\begin{array}{cc}4.7 & 19.4 \\ - & + \\ 3.90 & 16.5 \\ + & + \\ & \\ 0.14 & 4.74 \\ 4.30 & \\ 3.28 & 0.09 \\ + & 5.70 \\ - & - \\ - & + \\ 0.42 & + \\ + & 1.96 \\ + & + \\ & + \\ 9.06 & 1.93\end{array}$

CONCHOSTRACA

Cyclestheriidae, Cyclestheria hislopii (Baird)

CLADOCERA

Daphnidae, Simocephalus vetulus (Müller)

Macrothricidae, Grimaldina brazzai (Richard)

Chydoridae, Euryalona occidentalis (Sars)

COPEPODA

Microcyclops anceps (Ricard)

Macrocyclops albidus (Jurine)

AMPHIPODA

Hyalellidae, Hyalella curvispina (Shoemaker)

Trichodactylidae, Trichodactylus borellianus (Nobili)

Palaemonidae

Macrobrachium jelskii (Miers)

Macrobrachium amazonicum (Heller)

INSECTA

HEMIPTERA Adults

Belostomatidae, Belostoma micantulum (Stal)

Pleidae, Neoplea maculosa (Berg)

$\begin{array}{ll}0.26 & 0.03\end{array}$

Naucoridae, Pelocoris sp.

$0.16 \quad 0.33$

ODONATA larvae

Coenagrionidae

Libellulidae

Aeshnidae

EPHEMEROPTERA larvae

Caenidae, Caenis sp.

Baetidae, Callibaetis sp.

DIPTERA larvae and pupae

Culicidae, Mansonia sp.

Chironomidae

Tipulidae

Tabanidae

Ephydridae

Stratiomyidae

Syrphidae, Eristalis sp. 
TABLE 2 (Continued)

\begin{tabular}{|c|c|c|}
\hline & Pilcomayo & Paraná \\
\hline \multicolumn{3}{|l|}{ COLEOPTERA adults and larvae } \\
\hline Noteridae, Hydrocanthus sp. & 1.09 & 1.89 \\
\hline Scirtidae, Scirtes sp. & 0.07 & 1.15 \\
\hline Dytiscidae & 2.84 & 10.95 \\
\hline Laccophillus sp. and Desmopachria sp. & + & + \\
\hline Curculionidae, Neochetina bruchi (Hustache) and N. eichhorniae (Warner) & 0.84 & 1.12 \\
\hline Hydrophilidae & 3.27 & 4.60 \\
\hline Hydrochus richteri (Bruch) & + & + \\
\hline Derallus sp. & + & + \\
\hline Enochrus sp. & + & + \\
\hline Helochares sp. & + & + \\
\hline Berosus sp. & + & + \\
\hline Pselaphidae & - & 0.24 \\
\hline Staphylinidae & - & 0.54 \\
\hline Lampyridae & 0.2 & - \\
\hline LEPIDOPTERA larvae and pupae & 0.8 & 0.39 \\
\hline \multicolumn{3}{|l|}{ MOLLUSCA } \\
\hline Planorbidae, Drepanotrema sp. & 1.2 & 2.21 \\
\hline Ampullariidae, Pomacea canaliculata (Lamark) & - & 0.24 \\
\hline Hydrobiidae, Heleobia parchappii (d'Orbigny) & 30.5 & 1.43 \\
\hline Ancylidae & 2.02 & - \\
\hline Piscidae & 0.26 & - \\
\hline HIDRACNIDIA & 0.53 & 3.83 \\
\hline Total number of families & 33 & 34 \\
\hline
\end{tabular}

abundance (Fig. 3). Nitrate (0.96), dissolved oxygen (0.93), electrical conductivity (-0.92), roots dry weight $(-0.88)$, temperature $(0.88)$, roots length $(-0.85)$ and phosphate $(0.86)$ had the highest correlation values, whereas $\mathrm{pH}$ had the lowest one (0.62).

The proportion of the variance represented by the first and second NMDS axis was $93 \%$ and $0.82 \%$, respectively.

\section{DISCUSSION}

Our results indicated that E. crassipes growing in the Pilcomayo floodplain had longer leaves and less root biomass than those found in the Paraná floodplain, which is limited by nutrients. Previous studies carried out in floodplain lakes demonstrated that leaf height, leaf biomass, and root biomass respond to the influx of nutrients during the prolonged hydrologic connection with the Paraná River (Neiff, Casco, \& Poi, 2008). The density of the root in the Paraná floodplain influence oxygen concentration in the root zone by trapping organic matter and by preventing the re-aeration on the surface of the water. The low dissolved oxygen content within the floating meadows was attributable to intense heterotrophic activity in the E. crassipes roots (Carignan \& Neiff 1992). The position of Laguna Blanca (Pilcomayo floodplain) respect to the wind action and the short root system enable the mixture of the water and the oxygen dissolution.

The mean number of macroinvertebrates per square meter found in both floodplain was in the range observed previously in studies conducted with the same methods in the Paraná floodplain (Poi de Neiff \& Carignan 1997). Most of the registered taxa were common to both plains, but the abundance of some of them differed significantly. 


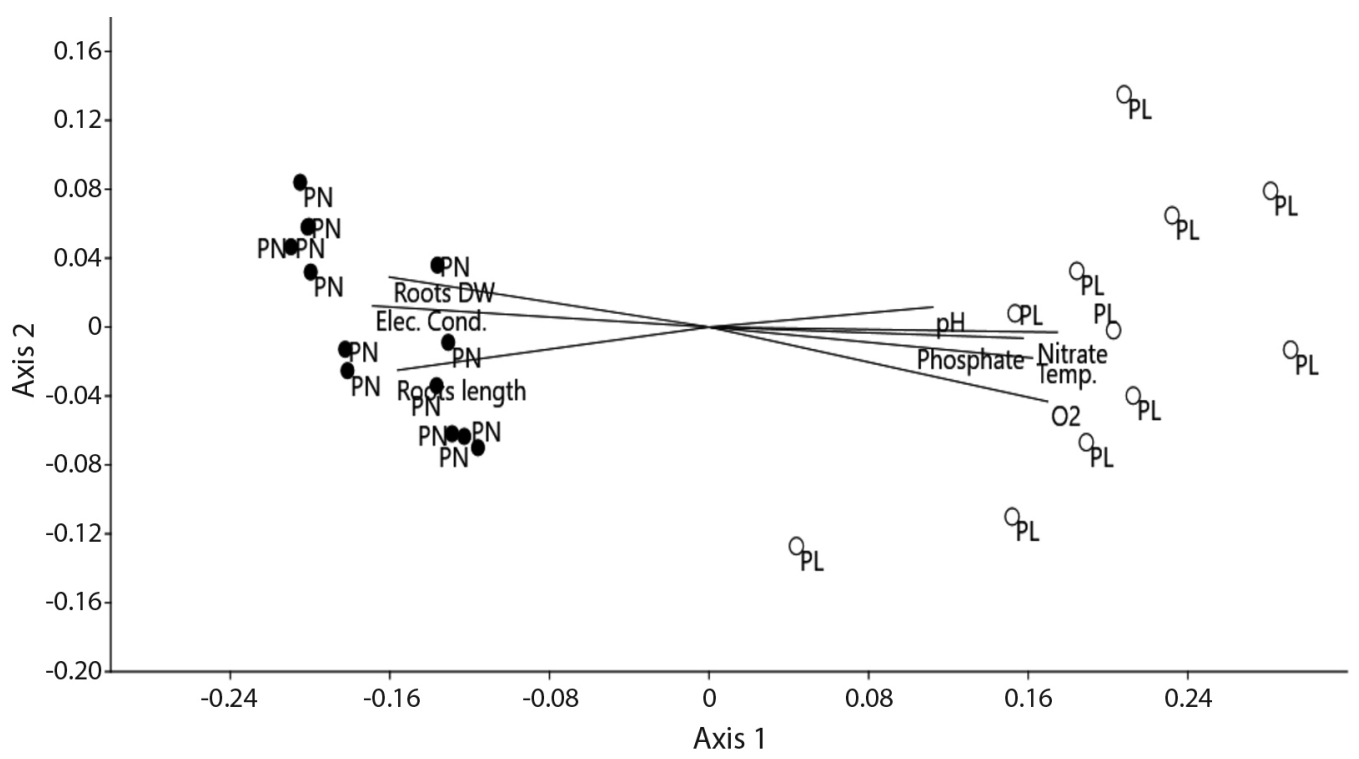

Fig. 3. NMDS ordination of environmental variables and the macroinvertebrate abundance (Ind. $\mathrm{m}^{2}$ ) in both floodplains. The proximity of symbols indicates a higher degree of similarities. Black and empty circles represent the samples collected in the Paraná and Pilcomayo floodplains, respectively. PN= Paraná, PL= Pilcomayo, Elec. Cond.= electrical conductivity, Roots $\mathrm{DW}=$ roots dry weight, Temp.= temperature.

The results of NMDS indicate that water conditions (temperature, dissolved oxygen, electrical conductivity, phosphate and nitrate content) of the studied floodplains, and roots biomass and length (which affect dissolved oxygen content in the floating meadows), are determinant of the composition of the macroinvertebrate assemblages. Phosphate and nitrate contents have a positive effect on the macroinvertebrate assemblages in the Pilcomayo floodplain because the highest concentration of nutrients encourages the trophic web that supports the macroinvertebrates.

The greater abundance of Naididae in the Paraná compared to the Pilcomayo River floodplain was expected because these oligochaetes are detritivores on the organic matter retain in the dense root systems and tolerant to low oxygen content. Oligochaeta dominated the macroinvertebrate assemblages during the decomposition of the leaves in the Paraná River floodplain (Poi de Neiff, Galassi, \& Franceschini 2009). Rocha-Ramirez, Ramirez-Rojas, Chavez-Lopez, and Alcocer (2007) attributed the abundance of Oligochaeta to detritus retention within the $E$. crassipes roots. Several families of beetles and bugs can live with low oxygen content by swimming to the surface to renew the air supply carried with them.

Rocha-Ramirez, Ramirez-Rojas, ChavezLopez \& Alcocer (2007) found a positive correlation between the density of amphipods and dissolved oxygen within the water hyacinth roots. Heleobia parchappii is an opportunistic species that can live in a wide range of salinities, except in anoxia conditions (Tietze 2011). Cyclestheria hislopii is a typical inhabitant of vegetation in shallow and permanent waters and many factors (habitat type, size of the water body, temperature and biotic conditions such as vegetation presence, competition and predation affect the population abundance (Maeda-Martínez, Belk, Barboza, \& Dumont 1997).

The prawns M. jelskii and M. amazonicum, collected in the Pilcomayo floodplain, were not found either in the present study or previous studies in the Paraná floodplain (Poi de Neiff \& Carignan 1997). Collins (2000) documented the occurrence of $M$. jelskii in Laguna Blanca, and extends its known range 
considerably southwards. Thus, the complete absence of these shrimps in the Paraná floodplain is related to its range of distribution rather than water conditions within the floating meadows. Montoya (2003) registered M. jelskii and M. amazonicum in E. crassipes roots growing in the Orinoco delta, with a mean density of $15.34 \pm 7.75$ ind. $\mathrm{m}^{2}$. The Amazon River prawn M. amazonicum is endemic to South America, where the species extends from Venezuela to Argentina, where isolated inland populations in the Upper Paraná and Paraguay Rivers were found (Pantaleão, Hirose, \& Costa 2014).

The species of Macrobrachium sp. are an important component of the food chain in limnetic environments, feeding on detritus, insect larvae, and plant fragments. In wetlands of the northeast of Argentina, H. curvispina acts as collector-gatherer and shredder, consuming detritus (the item with greatest proportion and frequency) and vegetal tissue (Poi, Galassi, Carnevali, \& Gallardo 2017).

The littoral cladoceran $S$. vetulus can evolutionarily adapt to quickly increased temperature (above $4{ }^{\circ} \mathrm{C}$ and $8{ }^{\circ} \mathrm{C}$ according IPCC scenario A2) in mesocosms experiment with more survival than those reared on cool water (Moss 2010). This species was cited by Heckman (2013) for the Pantanal de Poconé (Cuiaba, Basil) in warm waters.

The differences in the water condition between both floodplains and the root dry weight affect the composition and the dominance of macroinvertebrate assemblages. These differences affect the overall abundance, but not the taxa richness. E. crassipes forms larger floating meadows than other plants in the floodplain area with frequent horizontal flows from/to the river course and provides a unique habitat that contributes to overall biotic diversity, which must be considered in management strategies.

Our results indicate that the roots of the same floating plant (E. crassipes) growing under different environmental conditions may have different assemblages of macroinvertebrates. Forecasts for different Climate Change scenarios in the NE region of Argentina indicate that during this century a 2-3 degree increase in maximum temperatures is expected (Neiff \& Neiff 2013). The waters of Laguna Blanca, due to its proximity to the Tropic, were warmer, with little seasonal variability and difference of seven degrees Celsius respect to El Puente oxbow. However the higher temperature of the Pilcomayo floodplain has not a negative impact on the overall abundance per area and species richness of the macroinvertebrates, although affects the composition of the assemblages. According to Moss (2010), some of the change that might be occur as temperature increased, could be in relative abundance of species already present. Exist also the probability of evolutionary change in some organisms, especially the smallest, to the new conditions.

Ethical statement: authors declare that they all agree with this publication and made significant contributions; that there is no conflict of interest of any kind; and that we followed all pertinent ethical and legal procedures and requirements. All financial sources are fully and clearly stated in the acknowledgements section. A signed document has been filed in the journal archives.

\section{ACKNOWLEDGEMENTS}

The authors appreciate the valuable suggestions of the anonymous reviewers and the editor for substantial contributions to improve the present manuscript. We thanks to Pablo Collins for the identification of the shrimp of Laguna Blanca and Margarita Frutos for identification of the cladocerans and copepods. We also thanks to the authorities of Pilcomayo National Park for their logistical support and to Juan Iwazskiw for his valuable collaboration.

\section{RESUMEN}

Introduccion: Eichhornia crassipes es la planta acuática dominante en la planicie de inundación de los ríos tropicales y ha invadido las aguas cálidas de diferentes continentes. Las plantas proveen alimento y hábitat para los peces, especialmente Prochilodus linneatus y 
Gymnotus omarorum, que son relevantes para la pesca de subsistencia de las comunidades indígenas locales. Objetivo: En el presente trabajo nosotros describimos las principales características de las formaciones flotantes de E. crassipes, y analizamos la abundancia y composición de los ensambles de macroinvertebrados asociados a sus raíces en dos humedales de las planicies de inundación de los ríos Paraná (dentro del sitio Ramsar Humedales Chaco) y Pilcomayo (dentro del Parque Nacional Río Pilcomayo). Métodos: Durante la primavera y el verano, los macroinvertebrados se recolectaron en formaciones monoespecíficas de E. crassipes con una red de $962 \mathrm{~cm}^{2}$ y $500 \mu \mathrm{m}$ de tamaño de malla. La densidad de hojas, la biomasa de hojas y raíces, la longitud de las hojas y raíces y la calidad del agua se midieron simultáneamente. Resultados: La temperatura, la concentración de oxígeno disuelto y el contenido de nutrientes fueron significativamente mayores y la conductividad eléctrica fue significativamente menor en la planicie de inundación del Pilcomayo que en la del Paraná. Las plantas de E. crassipes que crecen en la planicie de inundación del Pilcomayo tuvieron hojas más largas y menos biomasa de raíces que las encontradas en la planicie del Paraná. El número de macroinvertebrados por $1000 \mathrm{~g}$. de peso seco de la raíz y por $\mathrm{m}^{2}$ fueron significativamente diferentes entre ambas planicies de inundación, pero la riqueza de taxa fue similar. El análisis de Escalamiento Multidimensional No Métrico diferenció la abundancia de los 14 taxa seleccionados entre ambas planicies de inundación, y mostró alta correlación entre las variables ambientales y la abundancia de los macroinvetebrados. Los grupos taxonómicos más abundantes en la planicie de inundación del río Paraná fueron los oligoquetos (Naididae), los ostrácodos, principalmente Cytheridella ilosvayi y las larvas de mosquitos no picadores (Chironomidae). Dos familias, Hydrobiidae (Heleobia parchappii) y Chironomidae representaron el 49,3\% de la abundancia total en la planicie de inundación del Pilcomayo. Los camarones Macrobrachium jelskii y M. amazonicum, frecuentes en la planicie de inundación del Pilcomayo, no se encontraron en la planicie de inundación del Paraná. Conclusiones: Las diferentes condiciones ambientales en ambas planicies de inundación afectan la abundancia, composición y la dominancia de los ensambles de macroinvertebrados; sin embargo, la riqueza total de taxa fue similar. El área ocupada por E. crassipes en la planicie de inundación de estos ríos proporciona el hábitat que más contribuye a la diversidad biótica, lo que debe ser considerado en las estrategias de manejo.

Palabras clave: jacinto de agua; ríos Paraná y Pilcomayo; planicies de inundación; abundancia de macroinvertebrados, riqueza de taxa.

\section{REFERENCES}

APHA, AWWA, WEF (American Public Health Association, American Water Works Association, Water Environment Federation). (1995). Standard methods for the examination of water and wastewater, 19th edn. APHA, AWWA, WEF, Washington DC.

Batzer, D. P., \& Wissinger, S. A. (1996). Ecology of insect communities in non tidal wetlands. Annual Review of Entomology, 41, 75-100.

Blanco Belmonte, L., Neiff, J. J., \& Poi de Neiff, A. (1998). Invertebrate fauna associated with floating macrophytes in the floodplain lakes of the Orinoco (Venezuela) and Paraná (Argentina). Verh. Internat. Verein. Limnol. (International Association of Theoretical and Applied Limnology, Stuttgart, Alemania), 26, 2030-2034.

Carignan, R., \& Neiff, J. J. (1992). Nutrient dynamics in the floodplain ponds of the Paraná River (Argentina) dominated by Eichhornia crassipes. Biogeochemestry, 17, 85-121.

Carignan, R., Neiff J. J., \& Planas, D. (1994). Limitation of water hyacinth by nitrogen in subtropical lakes of the Paraná floodplain (Argentina). Limnology and Oceanography, 39, 439-443.

Collins, P. (2000). A new distribution record for Macrobrachium jelskii in Argentina (Decapoda, Palaemonidae). Crustaceana, 73, 1167-1169.

Di Rienzo, J. A., Casanoves, F., Balzarini, M. G., Gonzalez, L. M., Tablada, C., \& Robledo, W. (2013). InfoStat. Grupo InfoStat, FCA, Universidad Nacional de Córdoba, Argentina. URL http://www.infostat.com.ar.

Domínguez, E., \& Fernández, H. R. (2009). Macroinvertebrados bentónicos sudamericanos. Sistemática y biología. Fundación Miguel Lillio. Tucumán, Argentina.

Ferriz, R. A., \& Iwaszkiw, J. M. (2014). Alimentación de Gymnotus omarorum (Gymnotiformes: Gymnotidae) en Laguna Blanca (Parque Nacional Río Pilcomayo), Formosa, Argentina. Revista del Museo Argentino de Ciencias Naturales, 16, 115-122.

Franceschini, M. C., Poi de Neiff, A., \& Galassi, M. E. (2010) Is the biomass of water hyacinth lost through herbivory in native areas important? Aquatic Botany, 92, 250-256.

Hammer, Ø., Harper, D. A. T., \& Ryan, P. D. (2001). PAST: Paleontological statistics software package for education and data analysis. Palaeontología electrónica. URL http://palaeo-electronica.org.

Heckman, C. W. (2013). The Pantanal of Poconé. Biota and ecology in the northern section of the world's largest pristine wetlands. Springer Science \& Business Media, B.V., Dordrecht, Holanda.

Libonatti, M. L., Michat, M. C., \& Torres, P. L. M. (2011). Key to the subfamilies, tribes and genera of adult Dytiscidae of Argentina (Coleoptera: Adephaga). Revista de la Sociedad Entomológica Argentina, 70, 317-336. 
Maeda-Martínez, M. A., Belk, D., Barboza, O. H., \& Dumont, H. J. (1997). Large branquiopod assemblages common to Mexico and the United States. Hydrobiologia, 359, 45-62.

Michat, M. C., Archangelsky, M., \& Bachmann, A. O. (2008). Generic keys for the identification of larval Dytiscidae from Argentina (Coleoptera: Adephaga). Revista de la Sociedad Entomológica Argentina, 67, 17-36.

Montoya, J. (2003). Freshwater shrimps of the genus Macrobrachium associated with roots of Eichhornia crassipes (water hyacinth) in the Orinoco Delta. Caribean Journal of Science, 39, 155-159.

Moss, B. (2010). Ecology of freshwaters: a view for the twenty-first century. Chichester: Willey Blackwell.470 pp.

Neiff, J. J., Casco, S. L., \& Poi de Neiff, A. (2008). Response of Eichhornia crassipes (Pontederiaceae) to water level fluctuations in two lakes with different connectivity in the Paraná River floodplain. Revista de Biología Tropical, 56, 613-623.

Neiff, J. J., Poi de Neiff, A., \& CanónVerón, M. B. (2009). The role of vegetated areas on fish assemblage of the Paraná River floodplain: effects of different hydrological conditions. Neotropical Ichthyology, 7, 39-48.

Neiff, J. J., \& Neiff, M. (2013). Evaluación de los impactos del cambio climático sobre el ecosistema natural y la biodiversidad. Esteros del Iberá (Argentina). CEPAL - Serie Medio Ambiente y Desarrollo $N^{\circ}$ 152: 1-59. ISSN: 1564-4189. Publicación de las Naciones Unidas, Chile.

Neiff, J. J., Casco, S. L., Mari, E. K., Di Rienzo, J. A., \& Poi, A. (2014). Do aquatic plant assemblages in the Paraná River change along the river's length? Aquatic Botany, 114, 50- 57.

Pantaleão, J. A. F., Hirose, G. L. B., \& Costa, R. C. (2014). Ocurrence of male morphotypes of Macrobrachium amazonicum (Caridea, Palaemonidae) in a population with an entirely freshwater life cycle. Brazilian Journal of Biology,74, 223-232.
Poi, A. S. G., Galassi, M. E., Carnevali, R. P., \& Gallardo, L. I. (2017). Leaf litter and invertebrate colonization: the role of macroconsumers in a Subtropical wetland (Corrientes, Argentina). Wetlands, 37,135-143.

Poi de Neiff, A., \& Carignan, R. (1997). Macroinvertebrates on Eichhornia crassipes roots in two lakes of the Paraná River floodplain. Hydrobiologia, 345, 185-196.

Poi de Neiff, A., \& Neiff, J. J. (2006). Riqueza de especies y similaridad de los invertebrados que viven en plantas flotantes de la planicie de inundación del río Paraná. Interciencia, 31,220-225.

Poi de Neiff, A., Galassi, M. E., \& Franceschini, M. C. (2009). Invertebrate assemblages associated with leaf litter in three floodplain wetlands of the Paraná River. Wetlands, 29, 896-906.

Ramirez, A. (2010). Odonata. Revista de Biología Tropical, $58,97-136$

Rocha-Ramirez, A., Ramirez-Rojas, A., Chavez-Lopez, R., \& Alcocer J. (2007) Invertebrate assemblages associated with root masses of Eichhornia crassipes (Mart.) Solms-Laubach 1883 in the Alvarado Lagoonal System, Veracruz, México. Aquatic Ecology, 41, 319-333.

Thomaz, S. M., Dibble, E. D., Evangelista, L. R., Higuti, J., \& Bini, L. M. (2008). Influence of aquatic macrophyte habitat complexity on invertebrate abundance and richness in tropical lagoons. Freshwater Biology, $53,358-367$.

Tietze, E. (2011). Distribución de Heleobia parchappii. Sociedad Malacológica de Chile (SMACH) Amici Molluscarum, Número especial, 73-75.

USEPA (2002). Methods for evaluating wetland conditions: \#9 developing and invertebrate index of biological integrity for wetlands. United States Environmental Protection Agency. Office of Water, Washington, DC, USA. EPA-822-R-02-019.

Villamagna, A. M., \& Murphy, B. R. (2010). Ecological and socioeconomic impacts of invasive water hyacinth (Eichhornia crassipes): a review. Freshwater Biology, 55, 282-298. 